International Journal of Instruction e-ISSN: 1308-1470 • www.e-iji.net

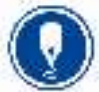

July $2021 \bullet$ Vol.14, No.3

p-ISSN: 1694-609X

pp. 223-240

Article submission code:

20200708170912

Received: 08/07/2020

Revision: 08/12/2020
Accepted: 31/12/2020

OnlineFirst: 24/04/2021

\title{
The Beliefs of Primary School Teachers: A Comparative Analysis
}

\section{Elena López Luján}

Prof., Universidad Católica de Valencia, Spain,elena.lopez@ucv.es

Teachers are a fundamental factor of quality in the educational process. Their professional beliefs configure teaching behaviours and conduct. The aim of this research was to analyse the professional beliefs of primary education teachers in the city of Valencia and to carry out a comparison between these beliefs and the variables Gender, Age, Professional Experience, Type of school and If they have children. A mixed methodology was used: quantitative, qualitative and comparative. We applied the Questionnaire on Teaching Competencies of Primary Education teachers, prepared, ad hoc, following the theoretical Model of Planned Action. A total of 371 teachers participated in the study, from both state schools and concertado (sponsored by a public voucher system) schools. After applying the appropriate statistics, the following results were obtained. Teachers perceived themselves to have very positive beliefs about the teaching-learning process in general terms. Significant differences were found according to gender, age, professional experience and type of school. In conclusion, a high self-perception regarding professional beliefs was found in all the teachers analysed.

Keywords: teaching competences, teachers' beliefs, theory of planned action, teacher training

\section{INTRODUCTION}

The quality of an educational system cannot be greater than the combined quality of the teachers. This statement was the most important conclusion of the Mckinsey Report (Mourshed et al., 2012) on the most common factors in the performance of the best educational systems. Similarly, the Hattie (2017) and Day (2019) reports demonstrated the impact of teachers' personal and pedagogical qualities on the educational performance of students. For Hattie, teacher credibility was the fourth most influential factor, along with a passion for teaching (Jordán y Codana, 2019).

Therefore, it is essential to analyse the professional competencies of teachers, since it allows us to discover teachers' beliefs, skills, attitudes, subjective norms, conduct intentions and behaviours, as well as identify possible deficiencies and/or training needs. In this paper, we will focus solely on the beliefs of teachers. According to the Theory of Planned Action (Ajzen and Fishbein, 1980; Steinmetz et al., 2016) beliefs are the subject's cognitions that performing a certain behaviour will result in benefits, as well as also the perception of what their social references expect from them and how their

Citation: Luján, E. L. (2021). The beliefs of primary school teachers: A comparative analysis. International Journal of Instruction, 14(3), 223-240. https://doi.org/10.29333/iji.2021.14313a 
abilities are perceived for the achievement of the desired outcome through their behaviour. This encompasses their ideas, values, opinions, information, stereotypes, etc. (Escámez, 2019: 223). Under this Theory all the elements are interrelated, so that the modification of one of them affects the others. The information that the subject possesses is embodied in personal beliefs, which are, in turn, the basis of their conduct. Therefore, in view of the studies that call into question the quality of the training of some teachers, it is believed necessary that knowing the beliefs of teachers about their teaching skills, helps us to predict their professional behaviors, detect their shortcomings and / or weaknesses and develop specific teacher training policies with the aim of improving the quality of teachers.

\section{Teaching Competences of Teachers}

The concept Competency comes from the Greek terms egon and agonistes that made reference to the subject prepared to succeed. Etymologically, it derives from the Latin verb competere (to go to meet one thing from another, to coincide), which evolves into the verbs to be the responsibility of and to compete. This division into two verbs - only occurs in Spanish - with different meanings (to belong and to involve, on the one hand and to fight or to compete, on the other) implies a certain ambiguity. We opt for the meaning to be the responsibility of/competency, in harmony with concepts such as: ability, aptitude or suitability.

The earliest studies that speak of competences are those of Levy-Levoyer (1997), where they were linked to the abilities of professionals to carry out the tasks of their job. Shortly after, the research article of Le Boterf (2001) appeared, which added the qualities of professionalism and combinatorial knowledge to this concept. Currently, the concept of competence has been established in the educational field. Although, this attempt to reassess Know-How has not always been well understood. In this sense, Perrenoud (2012) complained that some socioeconomic and educational sectors were misusing this concept, derived from an attempt at commercialising education and the loss of teaching autonomy (Day, 2020).

\section{What are Teaching Competencies?}

The teaching task has also been included under the umbrella of the concept of competence. The preparation, training and ability of teachers for the performance of their professional work is measured, today, under the perspective of teaching skills and pedagogical leadership (González et al., 2019). We could define these as the integrated set of personal, cognitive, pedagogical and attitudinal qualities necessary for effective performance in specific contexts (Meirieu, 2019).

Zabalza (2003) defines them as the ethical, emotional and cognitive knowledge that a teacher needs to implement their pedagogical task. This adds a new factor: the emotional aspect. This is an emotional dimension of a multi-directional nature, since it takes into account everything that affects care (Noddings, 1996) and sensitivity to the emotions of others - students, colleagues and/or families - (van Manen, 2010) and, in addition, is attentive when managing the teacher's own emotions, facilitating proper interpersonal relationships and preventing burnout (Salgado and Leria, 2018). Meirieu (2019), 
meanwhile, adds the transfer value. He defines the competent teacher as someone capable of solving the problems derived from the teaching-learning process in concrete, new and different situations. Miguel Martínez (2016) said that the teacher must be able to face complexity and uncertainty, from a social and ethical perspective. It is about defining the teaching task as a moral task (Sanger and Osguthorpe, 2011) and reflexive (Ivanova-Armeykova, 2020).

As observed, there are different conceptions of the concept of teacher competence. Each one of them, emphasizes different aspects; cognitive, personal, pedagogical, social, emotional (Barrientos et al. 2020). For example, Fraboni (2003) talks about Theoretical, Operational, Interaction-Related and Deontological Competences. Galvis (2007) defines them as Intellectual, Professional, Social, Interpersonal and Intrapersonal. Pesquero (2008) classifies them, by order of importance: Focused on learning, Related to social skills and Teacher personality. Armengol et al. (2011) as: Instrumental, Emotional and Social. Gairin (2011) as: Technical, Methodological, Social and Personal. The Spanish Ministry of Education of the Regional Government of Castile and León (2012) defines them according to the type of Knowing: "Saber hacer qué, Saber hacer cómo y Saber estar" (to Know, to Know what, to Know how and to Know how to behave). Also Valdemoros and Lucas (2014) define them as to Know how and to Know how to be. Finally, Fernández et al. (2016) classify them as Instrumental and Interpersonal.

For our part, we follow the Theory of Planned Action, which allows us to recognise the Beliefs of Primary Education teachers (knowledge and values), their Skills, Attitudes, Subjective Norms, Conduct Intentions and Professional Behaviours. Identifying the beliefs of teachers is the basis for assessing their intentions and, therefore, predicting their behaviour (Figure 1).

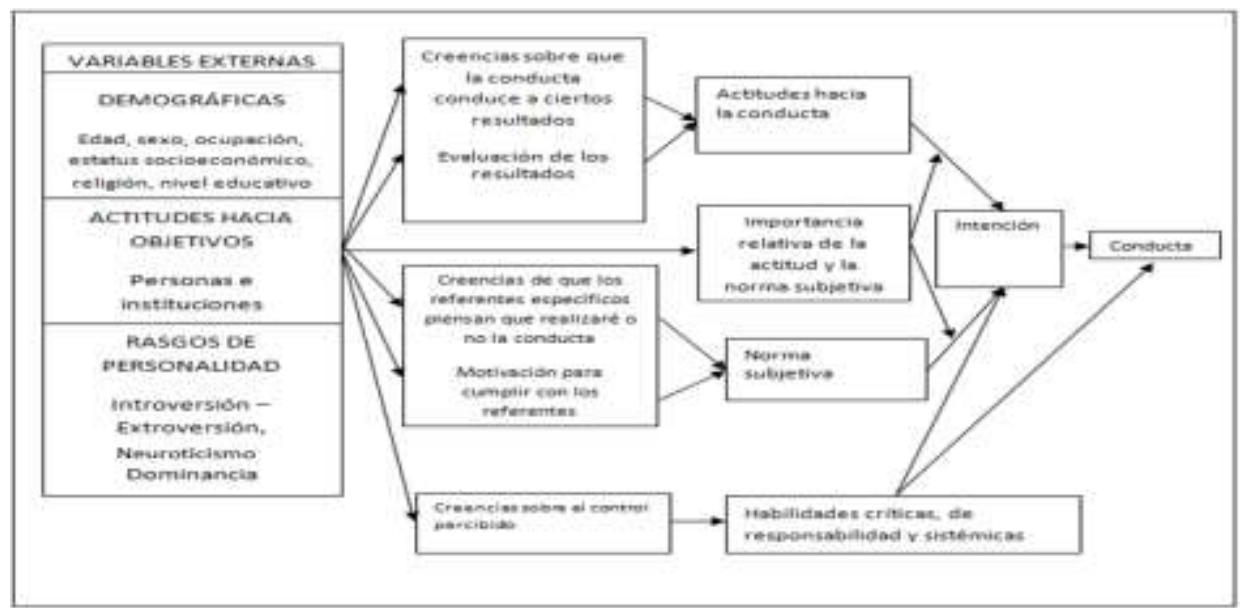

Figure 1

Outline of the theory of planned action (Escámez, 2019) 


\section{METHOD}

This research follows a plural methodological approach, which combines the quantitative, qualitative and comparative approaches. The beliefs of primary school teachers were analysed from the empirical-analytical perspective. From the hermeneuticinterpretive perspective, the meanings and intentions of people's actions, behaviours or decisions were unravelled through the interpretation of their discourses. And finally, from the comparative method, teacher profiles were established based on gender, age, professional experience, type of school where they work and if they have children. All this information enabled identification of possible deficits and/or deficiencies in training shown by Primary Education teachers, so that it is subsequently possible to implement continuous training programs.

\section{Purpose}

This article analysed the teaching beliefs of primary education teachers in the city of Valencia and compared these beliefs against the variables of gender, age, professional experience, type of school and if the teacher had children of their own. From this comparison we obtained an overview of the beliefs of the teaching staff that allowed us to classify them into specific profiles according to the variables.

\section{Instrument}

We used the Scale Questionnaire on Competences of Primary Education Teachers, applied ad hoc under the principles of the Theory of Planned Action. This Theory allows us to predict teacher 'behaviours based on their Beliefs, Attitudes, Skills, Subjective Norms and Behavioural Intentions.

A discussion group and a commission of experts in Primary Education put forward the first formulation of the questionnaire items, and all the proposals were submitted to evaluation and judgement. Subsequently, a pilot study was carried out in order to validate the questionnaire and to debug those items that could present problems ( $\mathrm{n}=$ 154). During this process, we went from the initial 97 proposals to a pilot questionnaire made up of 65 items, until reaching a final questionnaire made up of 60 items, on a Likert scale with 5 responses, where 1 was Totally Disagree and 5 was Totally Agree. The questionnaire was divided into 6 factors, following the Theory of Planned Action and its reliability (Cronbach's alpha $=0.917)$ and validity $(\mathrm{KMO}=0.757)$ were excellent. The items that made up the Teacher Beliefs Factor are shown in Table 1. 
Table 1

Relationship of teachers' belief factor items

5. I am not prepared to resolve or manage conflicts in the classroom or at the school

6. I do not need to know new assessment techniques to know about student learning

22. I don't organize students to work in groups

29. It is not my function to properly observe and interpret possible risk behaviours of students (addictions, abuse, etc.)

40. It is not my function to promote the values of civil ethics in students: freedom, equality, solidarity, justice, tolerance, responsibility and peace.

41. I do not consider the teaching of Human Rights necessary

47. I do not see it necessary to face the duties and ethical questions of the teaching profession

48. Education for sustainability is a waste of time

53. I do not believe that the regular use of ICT resources and apps for pedagogical purposes is necessary

60. It is not my business that the students adopt thoughts and decisions for themselves

\section{Characteristics of The Sample}

The sample was made up of Primary Education teachers, both from public schools and concertado (schools sponsored by a public voucher system), from the city of Valencia. To ensure that the sample was representative, the formula to determine finite populations was used, with a confidence level of $95 \%$ and an estimation error of $5 \%$.

The minimum sample required was $\mathrm{n}=354$ Primary Education teachers out of the total 4440 teachers in the city of Valencia, according to data from the Valencian Regional Ministry of Education, Culture and Sports for the year 2019-2020. Of these 354 teachers, 160 had to be from public schools (45\%) and 194 from concertado schools (55\%), from a total of 2030 teachers in public schools and from 2410 from concertado schools. The final sample was $\mathrm{n}=371$ (Table 2, Table 3):

Table 2

Characteristics of the sample

\begin{tabular}{llr}
\hline \multirow{2}{*}{ GENDER } & Man & $74,4 \%$ \\
\cline { 2 - 3 } TYPE OF SCHOOL & Woman & $25,6 \%$ \\
\hline \multirow{2}{*}{ CHILDREN } & Public & $43,9 \%$ \\
\hline \multirow{2}{*}{ PROFESSIONAL EXPERIENCE } & Concertado & $56,1 \%$ \\
\cline { 2 - 3 } & Yes & $39,4 \%$ \\
\cline { 2 - 3 } & Less than 10 years old & $36,6 \%$ \\
\cline { 2 - 3 } & Between 11-20 years old & $27,8 \%$ \\
\cline { 2 - 3 } & Between 21-35 years old & $9,7 \%$ \\
\cline { 2 - 3 } AGE & More than 35 years old & $24,2 \%$ \\
& From 20-30 years old & $24,5 \%$ \\
& From 31-40 years old & $28 \%$ \\
\cline { 2 - 3 } & From 41-50 years old & More than 51 years old \\
\cline { 2 - 3 } & &
\end{tabular}

International Journal of Instruction, July $2021 \bullet$ Vol.14, No.3 


\section{Statistics}

The statistics used for the descriptive analysis of the responses to the questionnaire were the mean, mode, standard deviation and variance of each of the items based on the professional beliefs of teaching staff. For the comparative study, the Chi-square statistic was used, which allowed us to check if two variables were related to each other, that is, if they are independent of each other, as well as the analysis of the response percentages to graphically observe the differences found.

\section{FINDINGS AND DISCUSSION}

First, we present the data as obtained from the statistical analysis. This first overview showed the responses on the Professional Beliefs of Primary Education teachers questionnaire in general and absolute terms. Subsequently, we present the commentary and discussion of these results, offering a critical interpretation and comparing the results with other similar investigations. In the second section, we performed a comparison based on the variables gender, age, professional experience, type of school and whether the teachers have children of their own.

\section{Descriptive analysis of the Beliefs of Primary Education Teachers}

Table 3 shows the mode for each of the different items is: Value 1. The mode is the number that occurs most often in a data set. We must bear in mind that all the items were formulated in a negative way.

Table 3

Mean, mode and standard deviation teacher beliefs factor

\begin{tabular}{|c|c|c|c|c|c|c|c|c|c|c|}
\hline & 5. & 6. & 22. & 29. & 40. & 41. & 47. & 48. & 53. & 60. \\
\hline Valid & 371 & 371 & 371 & 371 & 371 & 371 & 371 & 371 & 371 & 371 \\
\hline Mean & 2,09 & 1,70 & 1,37 & 1,16 & 1,17 & 1,16 & 1,34 & 1,26 & 1,63 & 1,56 \\
\hline Mode & 1 & 1 & 1 & 1 & 1 & 1 & 1 & 1 & 1 & 1 \\
\hline Standard deviation & 1,196 & ,986 &, 717 & ,548 & ,573 & ,581 &, 734 & ,666 & 883 & ,894 \\
\hline
\end{tabular}

\section{Analysis of The Data}

The data show a very homogeneous trend in the responses to all the items. In all items, except for 5, 6, 53 and 60, over 90\% of the teachers' responses were Agree. Items 5, 6, 53 and 60 also had a very high percentage of Agree responses. In the case of item 5, this was over $70 \%$ and for items 6,53 and 60 , they were over $80 \%$. Therefore, there was good agreement among all the teachers investigated that: "They are prepared to resolve or manage conflicts in the classroom or at the school" $(70.1 \%)$; "They know novel evaluation techniques to identify student learning" (80.1\%); "They organize students to work in groups" (93.3\%); "It is their function to properly observe and interpret possible risk behaviours of students" (97.8\%); "It is their role to promote the values of civil ethics in students: freedom, equality, solidarity, justice, tolerance, responsibility and peace" (96\%); "They consider necessary the teaching of Human Rights" (95.4\%); "They see it necessary to face the duties and ethical questions of the teaching profession" (92.5\%); "They see education for sustainability as necessary" (93.3\%); "They believe 
that the regular use of ICT resources and apps for pedagogical purposes is necessary" $(83.6 \%)$; and "It is their business that students adopt thoughts and decisions for themselves" (84.4\%). The only data that were a little out of the norm were the percentage of Indifferent $(12.1 \%)$ and Disagree $(17.8 \%)$ as to whether they are prepared to resolve or manage conflicts in the classroom or in the school; and the percentage of Indifferent (11.9\% and $11.3 \%$, respectively) of those believing it is necessary to habitually use ICT resources for pedagogical purposes and if it is their business that students adopt thoughts and decisions for themselves.

\section{Commentary and Discussion of The Findings}

For the commentary and discussion of the results about the beliefs of Primary Education teachers, we divided them into two blocks. On the one hand, those beliefs of a pedagogical nature and, on the other, those of a moral nature.

In general terms, teachers' responses to pedagogical questions followed the same trend, although with nuances. For example, item 5, on the readiness of teachers themselves to respond to classroom conflicts, $17.8 \%$ of teachers had the belief of not feeling prepared, along with a $12.1 \%$ who were indifferent. These results reinforce the idea of the Marchesi and Díaz Report (2008), Las emociones y valores del profesorado (the emotions and values of teachers), where teachers stated that "Maintaining order in class" is one of the 3 most important problems of the educational process and the third most common deficiency as a teacher $(9.6 \%)$. The TALIS Report (2018) also reported in this same perception. Nearly $20 \%$ of Spanish and Valencian teachers stated that they needed training in classroom management. The data from the Region of Cantabria also showed certain similarities. A third of the teachers in this Region attended continuous training on conflict resolution and another third requested this training (García-Ruíz and Castro, 2012). These data demonstrate the need and the belief that teachers are not fully prepared to face this reality. Surveys of teachers internationally found slightly lower percentages on similar items. 59\% believed in controlling conflictive behaviours in the classroom; and $61 \%$ believed in persuading students to obey the class rules (OECD, 2017b). These percentages were higher in the last TALIS Report (2019), in which teachers' beliefs regarding whether they were capable of controlling disruptive behaviours increased up to $85 \%$; and $83 \%$ reported the belief that they were able to calm troubled students. These data are slightly higher than those of our study. In item 6, which raises the need to know new evaluation techniques, we also observed similar results; $80.1 \%$ of teachers believed they needed novel assessment techniques to cope with the wide diversity of learning styles, abilities, and rhythms of today's students. In this regard, Mas and Sanmartí (2017) call for a review of the design of the evaluation activities and a consensus on strategies to address diversity. These results contradict those of the study by Orozco and Moriña (2019) in which they state that teachers master various evaluation techniques. Again, the TALIS Report (2018) highlighted assessment practices as one of the greatest demands for teacher training (around 15\% in both Spain and the Region of Valencia). This helps us understand the importance of evaluation as a learning process and not just for certification and/or exclusion. Again the data from the Region of Cantabria confirmed this finding. Around 35\% of teachers were trained or 
have requested this training (García-Ruíz and Castro, 2012), which demonstrates the belief about the need for further training in this regard. Referring to the belief about the benefits of teamwork, item 22, we observed a shared trend. $93.3 \%$ of teachers admitted its importance. The Report How do teachers teach? Reflections by teachers and students (OECD, 2017a) showed a curious reality regarding teamwork by students. $90 \%$ of teachers affirmed that they included it within their teaching methodologies, while only $59 \%$ of students admitted this reality. These data lead us to reflect on whether teachers usually answer the questionnaires from a too positive view of their professional work. Item 29 is about understanding the teacher as an educator, rather than just a transmitter of knowledge. This item asks about the belief of whether the teacher should worry about identifying possible risk behaviours of students (addictions, abuse, etc.). There was a clear unanimity among the surveyed teachers. $97.8 \%$ believed that it was within their competence as a teacher. Derevensky, St-Pierre, Temcheff and Gupta (2014) agree on the importance of the teacher in this task. However, we observed in some reports, it was not always easy for them. The study by Caballo, Caride and Gradaílle (2012) contradicts these results, as it states that many teachers do not care about monitoring their students' risk behaviors. In that sense the biggest deficiency that teachers themselves perceive of themselves (Marchesi and Díaz, 2008) was "Understanding the most difficult students" (57.4\%). The last item included in the pedagogical questions was item 53. This asked about the need to use ICT as a teaching resource. Although we found a very high percentage of teachers believed that its use was necessary $(83.6 \%)$, we also found that almost $12 \%$ viewed it with indifference and $5 \%$ dismissed it. Today we live in a digital society, our students are digital and, possibly, this percentage of teachers who said they were indifferent to and who disregarded the importance of ICT were teachers with little training in the new technologies or who had not mastered these methodological tools. A study on the credibility of teachers analysed from the students' point of view affirmed that students granted greater credibility and competence to teachers who regularly used ICT as a teaching tool (Froment et al., 2019). A study in the Region of Madrid confirmed our belief that this percentage of teachers who were indifferent to or who rejected use of ICT, was normally due to lack of training and lack of command of the technologies. It demonstrates the existence of a digital gap (43.3\% of teachers), lack of security, and technological and pedagogical competence among teachers (Fernández-Cruz and Fernández-Díaz, 2016).

Regarding the results of the moral questions, we also found some homogeneity in the answers. Items 40, 41, 48 and 60 referred to beliefs about whether education should educate in values. These items ask whether education should include the values of civil ethics (item 40), Human Rights (item 41) and Sustainability (item 48). Again, we found very positive results (above $90 \%$ in all items). This trend coincides with the importance given in the educational field to these values, as can be seen in recent research by Professors Sanz and Serrano (2019) and Sanz et al. (2018). They also coincide with the statements of Hargreaves (2003), Nussbaum (2011), and others, that maintain that education for democracy, for citizenship and for the values of civil ethics is a moral mandate for teachers. Schools must become "laboratories of democracy" (Beaudoin, 2013), where students have the opportunity to experience and live the values and 
principles of democracy. By contrast, on item 60, regarding the belief that the teacher should promote autonomous and critical thinking among students, we observed certain discrepancies. Despite the high percentage of affirmative responses $(84.4 \%)$, we found $16.6 \%$ of teachers who disagreed. These data coincide with those of the OECD Report (2016) Pedagogical beliefs and practices, where $84 \%$ of teachers affirmed that students' reflection processes were more important than learning curricular content. Curiously, the training for democracy and citizenship that was previously demanded with very high percentages was not endorsed in the same way on this item. The last of the items, item 47, refers to the conviction whether the teacher should be an ethical professional. $96 \%$ of teachers believed that teaching is an ethical profession, that it concerns people and that their behaviours influence their training. For this reason, they were convinced that their actions as teachers must respond to a series of ethical values and principles and that the ultimate objective of education should be the training of a citizen to the level of dignity as a human being.

We observed that teachers in general had very high beliefs regarding their pedagogical and axiological competences, that is, they perceived themselves to have high professional and moral self-efficacy. The Ministry of Education and Vocational Training (MEFP, 2020), in the conceptual framework of the TALIS Program, associated teacher self-efficacy with good academic results, interest and motivation of students. Therefore, this high self-efficacy of our teachers should be correlated with high academic results of our students (see results of diagnostic tests in the Region of Valencia) and with high motivation for learning.

\section{Comparative Analysis of The Beliefs of Primary Education Teachers}

In this second section of analysis of the results we carried out a comparative study based on the variables gender, age, teaching experience, type of school and whether the teachers have their own children. The profile of the teachers in our survey is shown in Figure 2.

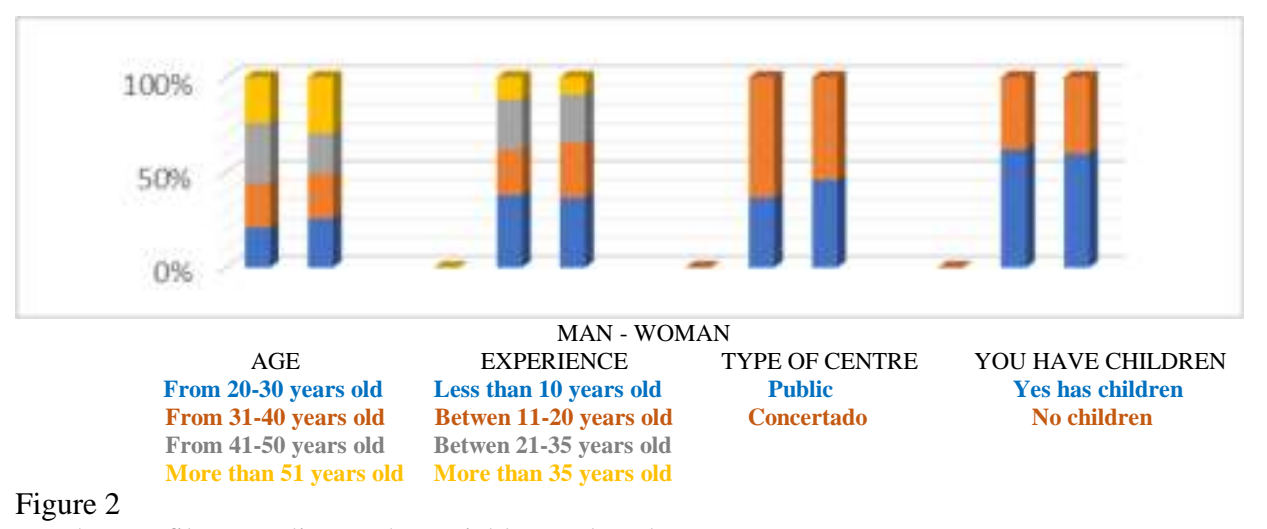

Teacher profile according to the variables analyzed 
In this analysis we will only mention those items in which we have found significant differences in any of these variables. We found that, in general terms, the responses to the items on Teacher Beliefs followed a very similar trend, although with some interesting differences.

\section{Analysis of The Data. Commentary and Discussion of The Results}

We found 2 (item 48 and item 53) significant differences in relation to the gender of the teachers who participated in this study.

Item 48 raised the belief about the need to dedicate time within the teaching-learning process to education for sustainability. The introduction of topics associated with the creation of a more sustainable world, training in a series of values that enhance sustainability among students and the attempt to raise awareness among students to implement sustainable ways of life should become a fundamental aspect within the academic curriculum (Escámez-Marsilla and López-Luján, 2019). After the analysis of the responses obtained, a significant difference of more than 10 percentage points was found in favour of female teachers (Table 3). This result denotes a feeling/belief and a greater concern on the part of women towards issues around sustainability. One possible explanation is the view that women are more concerned with issues related to care within the educational process. Generally speaking, women have been more intensively educated in what Noddings (1996) calls the "care ethic."

Table 4

Relationship of item 48 "Education for sustainability is a waste of time" with Gender of teachers

\begin{tabular}{|c|c|c|c|c|c|c|c|}
\hline & & & 1 & 2 & 3 & 4 & 5 \\
\hline \multirow{2}{*}{ GENDER } & Man & $\%$ & $74,7 \%$ & $13,7 \%$ & $10,5 \%$ & $1,1 \%$ & $0,0 \%$ \\
\hline & Woman & $\%$ & $85,5 \%$ & $9,4 \%$ & $3,3 \%$ & $0,7 \%$ & $1,1 \%$ \\
\hline
\end{tabular}

The second item with significant differences was No. 53. This item alerts us to the importance of the use of ICT for pedagogical purposes. Again, it is female teachers who scored more highly in this area than their fellow male teachers. This difference was greater than 15 percentage points and demonstrated a more favourable belief towards their use of ICT and towards the improvement of academic results through ICT implementation in the classroom (Table 5). These differences were also found in the study by Fernández-Cruz and Fernández-Díaz (2016), in exactly the same proportions: $65.3 \%$ for male teachers, $82.2 \%$ for female teachers. Other investigations have found significant differences according to age, affirming that the older the teacher, the less use and greater the difficulty (Marchesi and Díaz, 2008; Fernández-Cruz and FernándezDíaz, 2016), something that did not occur in our research. 
Table 5

Relationship of item 53 "I do not believe that the regular use of ICT resources and apps for pedagogical purposes is necessary" to Gender of teachers

\begin{tabular}{|c|c|c|c|c|c|c|c|}
\hline & & & 1 & 2 & 3 & 4 & 5 \\
\hline \multirow{2}{*}{ GENDER } & Man & $\%$ & $48,4 \%$ & $30,5 \%$ & $10,5 \%$ & $8,4 \%$ & $2,1 \%$ \\
\hline & Woman & $\%$ & $62,3 \%$ & $22,8 \%$ & $12,3 \%$ & $2,5 \%$ & $0,0 \%$ \\
\hline
\end{tabular}

Regarding Age, we only found one difference, for item 6. The belief by teachers of needing novel learning assessment techniques was more significant among younger teachers (Table 6). It was younger teachers who believed they need these techniques the most. This result is surely related to the experience and the ability of the most experienced teachers to read the academic and pedagogical reality. Another explanation could be that these teachers left the academy relatively recently and, therefore, were more aware of the need to continue training and learning.

Table 6

Relationship of item 6 "I do not need to know new assessment techniques to know about student learning" to the age of teachers

\begin{tabular}{llllrrr}
\hline & 1 & 2 & 3 & 4 & 5 \\
\hline \multirow{3}{*}{ AGE } & From 20-30 years old & $64,8 \%$ & $19,8 \%$ & $8,8 \%$ & $2,2 \%$ & $4,4 \%$ \\
\cline { 2 - 8 } & From 31-40 years old & $70,1 \%$ & $14,9 \%$ & $12,6 \%$ & $1,1 \%$ & $1,1 \%$ \\
\cline { 2 - 8 } & From 41-50 years old & $43,8 \%$ & $33,7 \%$ & $14,6 \%$ & $5,6 \%$ & $2,2 \%$ \\
\cline { 2 - 8 } & More than 51 years old & $52,9 \%$ & $21,2 \%$ & $21,2 \%$ & $2,9 \%$ & $1,9 \%$ \\
\hline
\end{tabular}

Again, the item that measured the need to have novel learning evaluation techniques showed significant differences, this time, in terms of teaching experience (Table 7). This finding has a certain logic, since it was the youngest teachers who believed that they needed these assessment techniques the most, but these are also the least experienced teachers - who in principle should be the same - who warned of this deficiency. Again, experience or closeness to the training period may be the reason for this result. What seems clear is that at older ages and greater teaching experience, there is less awareness of needing new techniques to face the evaluation process of students.

Table 7

Relationship of item 6 "I do not need to know new assessment techniques to know about student learning” to Professional Experience

\begin{tabular}{llrrrrr}
\hline & & 1 & 2 & 3 & 4 & 5 \\
\hline \multirow{3}{*}{$\begin{array}{l}\text { PROFESSIONAL } \\
\text { EXPERIENCE }\end{array}$} & Less than 10 years old & $71,5 \%$ & $14,6 \%$ & $8,8 \%$ & $2,2 \%$ & $2,9 \%$ \\
\cline { 2 - 7 } & Between 11-20 years old & $48,5 \%$ & $31,1 \%$ & $16,5 \%$ & $2,9 \%$ & $1,0 \%$ \\
\cline { 2 - 7 } & Between 21-35 years old & $51,6 \%$ & $23,2 \%$ & $17,9 \%$ & $3,2 \%$ & $4,2 \%$ \\
\cline { 2 - 7 } & More than 35 years old & $47,2 \%$ & $25,0 \%$ & $22,2 \%$ & $5,6 \%$ & $0,0 \%$ \\
\hline
\end{tabular}

Another difference regarding Teaching Experience was found around the conception of the rights, duties and ethical questions of the profession. Here we found an almost identical response between teachers with less experience, less than 10 years and teachers with experience greater than 35 years. Both groups had a more convinced belief, 
between 5 and 10 percentage points (Table 8), regarding the importance of knowledge of the rights, duties and ethical issues of the teaching profession. A plausible explanation can be found in the fact that the youngest, with less experience, are those who have just started in the profession and, therefore, are very aware of duties and ethical issues. By contrast, teachers with a long career, more than 35 years of practice, have reached a period of maturity and deep reflection that makes them observe the teaching profession from a more ethical perspective. Perhaps, the teachers who are in the intermediate bands are in full professional development, with management positions, family responsibilities, etc., which do not allow them to spend so much time on these issues.

Table 8

Relationship between item 47 "I do not see it necessary to face the duties and ethical questions of the teaching profession" and Professional Experience

\begin{tabular}{llccccc}
\hline & & 1 & 2 & 3 & 4 & 5 \\
\hline \multirow{3}{*}{$\begin{array}{l}\text { PROFESSIONAL } \\
\text { EXPERIENCE }\end{array}$} & Less than 10 years old & $81,8 \%$ & $12,4 \%$ & $2,9 \%$ & $1,5 \%$ & $1,5 \%$ \\
\cline { 2 - 6 } & Between 11-20 years old & $70,9 \%$ & $22,3 \%$ & $6,8 \%$ & $0,0 \%$ & $0,0 \%$ \\
\cline { 2 - 6 } & Between 21-35 years old & $74,7 \%$ & $14,7 \%$ & $7,4 \%$ & $3,2 \%$ & $0,0 \%$ \\
\cline { 2 - 7 } & More than 35 years old & $80,6 \%$ & $11,1 \%$ & $2,8 \%$ & $0,0 \%$ & $5,6 \%$ \\
\hline
\end{tabular}

Also, we found significant differences in relation to the type of school and the teachers' beliefs regarding their preparation to resolve and manage classroom or school conflicts. The teachers of concertado schools believed that they were more prepared (Table 9). Other research gives us statistically significant results based on gender; male teachers felt more prepared than female teachers, and on experience, teachers with experience between 21 and 30 years felt more prepared (Marchesi and Díaz, 2008). Our research did not confirm those results.

Table 9

Relationship item 5 "I am not prepared to resolve or manage conflicts in the classroom or at the school" with Type of School

\begin{tabular}{llrrrrrr}
\hline & & & 1 & 2 & 3 & 4 & 5 \\
\hline \multirow{2}{*}{ TYPE OF SCHOOL } & Public & $\%$ & $36,4 \%$ & $28,4 \%$ & $17,3 \%$ & $13,6 \%$ & $4,3 \%$ \\
\cline { 2 - 7 } & Concertado & $\%$ & $47,4 \%$ & $26,8 \%$ & $8,1 \%$ & $14,8 \%$ & $2,9 \%$ \\
\hline
\end{tabular}

\section{CONCLUSION}

Teachers are a key factor in the educational process. According to the theory of Planned Action by Ajzen and Fishbein, recognition of professional beliefs of teachers helps us to predict their conduct and behaviours in the classroom and in the teaching-learning process. Throughout this research we analysed the professional beliefs of the teachers of primary education in the city of Valencia, observing very high scores in all the items of the questionnaire, so we can conclude that this sample showed a high self-perception of their professional beliefs, as well as towards their educational and pedagogical work. However, it seems that if we look at the results of Valencian students in the various national and international evaluations, we can see that this high self-efficacy does not correspond with or match the results of these students. Therefore, we can affirm that 
these teachers tended to respond to our items in a very optimistic way or attending to what is expected of them and not so much reflecting the reality of their educational practice.

Regarding those items in which significant differences were shown on the variables analysed, we observed that female teachers had a more positive view of the value of sustainability and the use of information technologies and their influence on learning. Likewise, the youngest and least experienced teachers believed that they needed more training in assessment techniques and instruments to attend to the diversity of students in today's classrooms. Also, longer professional experience resulted in a greater conception of teaching as an ethical profession. Finally, it was the teachers in concertado schools who had the higher conviction that they were better able manage the conflicts that occurred in their classrooms and in their schools.

All these results allow us to elaborate a profile of the teacher of the city of Valencia and to analyze the possible deficiencies that they present in their educational practice, according to their socio-demographic characteristics. Therefore, as a future line of research, we propose the elaboration of Teacher Training Programs that respond to these deficiencies.

\section{REFERENCES}

Ajzen, I. \& Fishbein, M. (1980). Understanding attitudes and predicting social behavior. Englewood Cliffs, New Jersey: Prentice Hall.

Armengol, C., Castro, D., Jariot, M., Massot, M. \& Sala, J. (2011). El Practicum en el Espacio Europeo de Educación Superior (EEES): mapa de competencias del profesional de la educación. Revista de Educación, 354, 71-98.

Barrientos, A., Sánchez, R. y Pericacho, F.J. (2020). Competencias sociales y emocionales del profesorado de Educación Infantil y su relación con la gestión del clima de aula. Estudios sobre Educación, 38, 59-78.

Beaudoin, N. (2013). Una escuela para cada estudiante. La relación interpersonal, calve del proceso educativo. Madrid, España: Narcea.

Caballo, M.B.; Caride, J.A. \& Gradaílle, R. (2012). Entre los tiempos escolares y los tiempos de ocio: su incidencia en la vida cotidiana de los adolescentes que cursan la Educación Secundaria Obligatoria en España. Educar em Revista, 45, 37-56.

Consejería de Educación de la Junta de Castilla y León (2012). Modelo de Competencias Profesionales del Profesorado. Castilla y León: Dirección General de Calidad, Innovación y Formación del Profesorado.

Day, C. (2019). What is teaching about? Professionalism and the limitations of standards and competences. European Journal of Education, 54(3), 315-318.

Day, C. (2020). How teacher's individual autonomy may hinder student's academic progress and attainment: professionalism in practice. British Educational Research Journal, 46(1), 247-264. 
Derevensky, J.L.; St-Pierre, R.A.; Temcheff, C.E. \& Gupta, R. (2013). Teacher awareness and attitudes regarding adolescent risky behaviors: is adolescent gambling perceived to be a problem? Journal of Gambling Studies, 30(2), 435-451.

Escámez, J. (2019). La perspectiva cognitiva para la comprensión de las intenciones y la predicción de las conductas del estudiantado como agente de sostenibilidad. En A. Arrufat \& R. Sanz (coords). La ciudadanía europea como labor permanente. Valencia, España: Tirant lo Blanch, 211-232.

Escámez-Marsilla, J.I. \& López-Luján, E. (2019). La formación del profesorado universitario para la educación en la gestión de la sostenibilidad. Publicaciones, 49(1), 53-62.

Fernández, Mà., Rodríguez, J.M. \& Fernández, F.J. (2016). Evaluación de competencias docentes del profesorado para la detección de necesidades formativas. Bordón, 68(2), 85-101.

Fernández-Cruz, F.J. \& Fernández-Díaz, Ma J. (2016). Los docentes de la Generación Z y sus competencias digitales. Comunicar, 46(24), 97-105.

Frabboni, F. (2003). La nuova formazione iniziale degli insegnanti. Annali dell'Istruzione, XLXIX (1-2), 149-161.

Froment, F.; Bohórquez, M.R. \& García-González, A.J. (2019). Credibilidad docente. Una revisión de la literatura. Revista Internacional de la Teoría de la Educación, 32(1), 23-54.

Gairín, J. (2011). Formación del profesorado basada en competencias. Bordón, 63(1), 93-108.

Galvis, R.V. (2007). De un perfil docente tradicional a un perfil docente basado en competencias. Acción Pedagógica, 16, 48-57.

García-Ruíz, R. \& Castro, A. (2012). La formación permanente del profesorado basada en competencias. Estudio exploratorio de la percepción del profesorado de Educación Infantil y Educación Primaria. Educatio Siglo XXI, 30(1), 297-322.

González, R., Palomares, A., López-Gómez, E. y Gento, S. (2019). Explorando el liderazgo pedagógico del docente: su dimensión formativa. Contextos educativos, 24, 925 .

Hargreaves, A. (2003). Enseñar en la sociedad del conocimiento. Barcelona, España: Octaedro.

Hattie, J. (2017). Aprendizaje visible” para profesores. Maximizando el impacto en el aprendizaje. Madrid, España: Paraninfo.

Ivanova-Armeykova, R. (2020). On reflexive skills and competences of the teachers. Education Journal, 9(4), 99-104. 
Jordán, J.A. y Codana, A. (2019). La influencia del profesor apasionado en la mejora académica y el desarrollo personal de los alumnos. Estudios sobre Educación, 26, 3151.

Le Boterf, G. (2001). Ingeniería de las competencias. Barcelona, España: Gestión 2000.

Lévy-Leboyer, C. (1997). Gestión de las competencias. Barcelona, España: Gestión 2000 .

Marchesi, A. \& Díaz, T. (2008). Las emociones y valores del profesorado. Madrid, España: SM.

Martínez, M. (2016). La formación inicial de los maestros: una responsabilidad compartida. Bordón, 68(2), 9-16.

Mas, M. \& Sanmartí, N. (2017). ¿Es necesario y se puede transformar la evaluación? Aula de Innovación Educativa, 265, 55-59.

MEFP (2020). TALIS 2018. Marco conceptual. Madrid: Secretaría de Estado de Educación y Formación Profesional.

Meirieu, P. (2019). Riquezas y límites del enfoque por "competencias" del ejercicio de la profesión docente hoy. Pedagogía y Saberes, 50, 97-108.

Mourshed, M., Chijioke, C. \& Barber, M. (2012). Cómo continúan mejorando los sistemas educativos de mayor progreso en el mundo. Chile, Chile: McKinsey.

Noddings, N. (1996). Stories and affect in teacher education. Cambridge Journal of Education, 26(3), 435-447.

Nussbaum, M. (2011). Sin fines de lucro. Por qué la democracia necesita de las Humanidades. Buenos Aires, Argentina: Katz.

OECD (2016). Creencias y prácticas pedagógicas. París, Francia: OECD.

OECD (2017a). ¿Cómo enseñan los profesores? Reflexiones de profesores y alumnos. París, Francia: OECD.

OECD (2017b). ¿De qué manera los profesores adquieren conocimientos y seguridad en la gestión del aula? Percepciones de un estudio piloto. París, Francia: OECD.

Orozco, I. \& Moriña, A. (2019). Prácticas docentes para una pedagogía inclusiva en Educación Primaria: escuchando las voces del profesorado. Aula Abierta, 48(3), 331338.

Perrenoud, P. (2012). Cuando la escuela pretende preparar para la vida. ¿Desarrollar competencias o enseñar otros saberes? Barcelona, España: Graó.

Pesquero, E., Sánchez, M.E., González Ballesteros, M., Martín Del Pozo, R., Guardia, S., Cervelló, J., Fernández Lozano, P., Martínez Aznar, M. \& Varela, P. (2008). Las competencias profesionales de los maestros de Primaria. Revista Española de Pedagogía, 241, 447-466. 
Salgado, J.A. \& Leria, F. J. (2018). Síndrome de burnout y calidad de vida profesional percibida según estilos de personalidad en profesores de educación primaria. CES Psicología, 11(1), 69-89.

Sanger, M.N. \& Osguthorpe, R.D. (2011). Teacher education, preservice teacher beliefs, and the moral work of teaching. Teaching and Teacher Education, 27(3), 569-578.

Sanz, R. \& Serrano, A. (2019). Misión y visión de una educación para el siglo XXI: cómo generar sociedades justas y sostenibles. En M. Ledesma (coord.). Justicia y Educación. Saberes y prácticas inclusivas en América y Europa. Perú, Perú: Centro de Estudios Constitucionales, 21-44.

Sanz, R.; Escámez, J. \& Peris-Cancio, J.A. (2018). The capabilities approach and sustainability: towards and inclusive Pedagogy. Journal of Innovation \& Knowledge, $3(2), 76-81$.

Steinmetz, H., Knappstein, M., Ajzen, I., Schmidt, P. \& Kabst, R. (2016). How Effective are Behavior Change Interventions Based on the Theory of Planned Behavior? A Three-Level Meta-Analysis. Zeitschrift für Psychologie, 224(3), 216-233.

TALIS (2018). Estudio Internacional de la Enseñanza y del Aprendizaje. Informe español. Madrid, España: Ministerio de Educación y Formación Profesional.

TALIS (2019). Guía del profesorado TALIS 2018. Volumen I. París, Francia: OCDE.

Valdemoros, M.A. y Lucas, B. (2014). Competencias que configuran el perfil del docente de primaria: análisis de la opinión del alumnado de Grado en Educación Primaria. Aula Abierta, 42(1), 53-60.

van Manen, M. (2010). El tacto en la enseñanza. El significado de la sensibilidad pedagógica. Barcelona, España: Paidós.

Zabalza, M.A. (2003). Competencias docentes del profesorado universitario. España, España: Narcea. 


\section{ANNEX. QUESTIONNAIRE}

Como profesor...

1 Domino los contenidos de las diferentes áreas de conocimiento

2 Utilizo las estrategias y técnicas didácticas para la enseñanza de las diferentes áreas

3 Utilizo estrategias específicas para la organización y diseño de situaciones de aprendizaje

4 Utilizo métodos para implicar al alumnado en los procesos de su aprendizaje y trabajo

$5 \quad$ No estoy preparado para resolver o gestionar los conflictos en el aula o en el 142445 centro

6 No necesito conocer técnicas novedosas de evaluación para conocer los 11223445 aprendizajes del alumnado

$7 \quad$ Es necesario que todo el profesorado conozca el Proyecto Educativo del Centro en el que trabaja

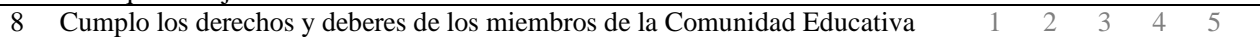

9 Son innecesarios los planes y programas específicos de la Comunidad Valenciana (PAT, Compensatoria, ...) que el Centro tiene en funcionamiento $\quad \begin{array}{llllll}2 & 2 & 3 & 4 & 5\end{array}$ para evitar el fracaso escolar

10 Las características psicoevolutivas y del desarrollo de su identidad del alumnado son necesarias en el proceso educativo

11 Mis compañeros creen que es necesario atender a las diferencias en los ritmos de aprendizaje

12 La formación de la libertad personal y el pensamiento crítico del alumnado no $\begin{array}{lllll}2 & 3 & 4 & 5\end{array}$ están en mis funciones como docente

13 Soy consciente de que la convivencia en el centro y en sus aulas reflejan las $12_{3}{ }_{4} 5$ tensiones sociales

14 Explico con claridad los contenidos de las áreas que imparto

15 Reflexiono y me evalúo a partir de la propia práctica docente

16 No tengo habilidades para argumentar y debatir

17 Escucho las preguntas e interrogantes que me formulan los estudiantes

18 Analizo críticamente los contenidos de las diferentes áreas

19 No pierdo el tiempo en analizar críticamente los acontecimientos que se $12_{3}{ }_{5}$ producen en la sociedad

20 Las habilidades para conducir el diálogo de los estudiantes en el aula son una $\begin{array}{llllll}2 & 2 & 3 & 4\end{array}$ necesidad docente

21 Gestionar adecuadamente el tiempo y los recursos del aula mejoran los 122344 resultados académicos

22 No organizo a los estudiantes para que trabajen en grupo

23 No sé anticiparme a los problemas de aprendizaje y prevenirlos

$24 \mathrm{Me}$ corresponde establecer las normas de funcionamiento y disciplina en el aula

25 Considero a mis estudiantes también como generadores de contenidos de aprendizaje

26 Genero un ambiente en el que las diferencias personales y culturales son 1424445 percibidas como enriquecimiento mutuo

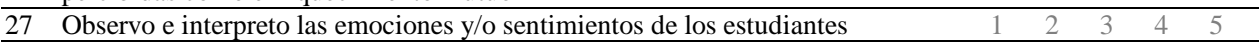

28 Me es difícil la relación con los compañeros, los alumnos y las familias de los $\begin{array}{llllll}1 & 2 & 3 & 4 & 5\end{array}$ alumnos/as

29 No es mi función observar e interpretar adecuadamente las posibles conductas de riesgo de los estudiantes (adicciones, maltrato, ...)

30 Sé motivar a los alumnos/as para el aprendizaje

31 Me siento responsable del aprendizaje del alumnado

International Journal of Instruction, July $2021 \bullet$ Vol.14, No.3 
\begin{tabular}{lllllll}
\hline 32 & Busco formación permanente en las diferentes áreas que imparto & 1 & 2 & 3 & 4 & 5
\end{tabular}

33 Me implico en los aspectos de innovación de la enseñanza

34 No estoy comprometido con la gestión de la diversidad cultural y personal de $\quad \begin{array}{lllll}2 & 3 & 4 & 5\end{array}$ los alumnos/as

\begin{tabular}{lllllll}
\hline 35 & Estoy dispuesto a trabajar en equipo con otros profesores/as & 1 & 2 & 3 & 4 & 5 \\
\hline
\end{tabular}

36 Estoy dispuesto a adaptar los contenidos a los diferentes ritmos de aprendizaje $1 \begin{array}{lllll}2 & 3 & 4 & 5\end{array}$ de los alumnos/as

37 No me siento comprometido en la colaboración con el Equipo Directivo del $1 \begin{array}{lllll}2 & 3 & 4 & 5\end{array}$ Centro

38 Considero la dimensión educativa como tarea de mi labor docente

39 La democracia es un valor que hay que salvaguardar

40 No es función mía promover en los estudiantes los valores de la ética civil: la libertad, la igualdad, la solidaridad, la justicia, la tolerancia, la responsabilidad $\quad 1 \quad 2 \quad 3 \quad 4 \quad 5$ y la paz

41 No considero necesaria la enseñanza de los Derechos Humanos

42 Respeto al alumno/a

43 Fomento la autoestima del alumnado

44 La diversidad cultural del alumnado distorsiona el funcionamiento del aula

45 Rechazo los prejuicios, el racismo y la discriminación

46 Creo que la participación del alumnado en el centro escolar es un aprendizaje para la futura participación en la sociedad civil

47 No veo necesario afrontar los deberes y las cuestiones éticas de la profesión docente

$48 \quad$ Es una pérdida de tiempo la educación para la sostenibilidad

49 Estimo el desarrollo de los conocimientos de las diferentes áreas y su investigación

$50 \quad$ No me gusta la profesión docente

51 La evaluación del aprendizaje de los alumnos tiene que ser igual para todos

52 Asisto a iniciativas para la formación continua en aspectos metodológicos

53 No creo necesario el uso habitual de recursos TIC y apps con fines pedagógicos

54 Informo a los padres/madres y hago lo posible por implicarles en el aprendizaje de sus hijas/os

55 Coopero y trabajo en equipo con los compañeros para poner en marcha 1424445 proyectos y programas del Centro

56 Gestiono los conflictos según lo establecido en el Plan de Convivencia e 1224345 Igualdad y los protocolos del RRI

57 Preparo las actividades como profesor atendiendo a la diversidad de $12_{3} 4{ }_{5}$ capacidades y culturas de los estudiantes

58 Mis comportamientos como docente son indiferentes para orientar las $1 \quad 2 \quad 3 \quad 4 \quad 5$ conductas del alumnado

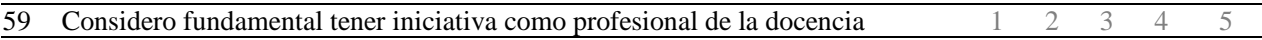

60 No es asunto mío que el alumnado adopte pensamientos y decisiones por él 1124345 mismo 